\title{
Ganglioglioma with novel molecular features presenting in a child with Allan-Herndon-Dudley syndrome
}

\author{
Jason W Adams, ${ }^{1}$ Denise Malicki, ${ }^{2}$ Michael Levy, ${ }^{3}$ John Ross Crawford ${ }^{4}$
}

${ }^{1}$ Neurosciences, University of California San Diego, La Jolla, California, USA

${ }^{2}$ Pathology, Rady Children's Hospital University of California San Diego, San Diego,

California, USA

${ }^{3}$ Neurosurgery, University of California San Diego, San Diego, California, USA

${ }^{4}$ Neurosciences and Pediatrics, University of California San Diego, La Jolla, California, USA

Correspondence to Dr John Ross Crawford; jrcrawford@ucsd.edu

Accepted 6 February 2022

Check for updates

(c) BMJ Publishing Group Limited 2022. No commercial re-use. See rights and permissions. Published by BMJ.

\begin{tabular}{|l|}
\hline To cite: Adams JW, \\
Malicki D, Levy M, et al. BMJ \\
Case Rep 2022;15:e248734. \\
doi:10.1136/bcr-2021- \\
248734 \\
\hline
\end{tabular}

\section{DESCRIPTION}

A boy with hemizygous SLC16A2 variant (Xq13.2; p.R371C) Allan-Herndon-Dudley syndrome (AHDS) presented with new-onset seizures. Physical examination revealed normal contour of the cranium and a normal hairline. The face exhibited a long and narrow profile, but individual features were unremarkable in size, shape or position. Neurological examination was notable for central hypotonia and developmental delay. MRI demonstrated a T2-hyperintense, T1-isointense cortical lesion along the left inferior mesial temporal lobe consisting of cystic and solid components, without reduced diffusivity, and multiple solid enhancing nodules on postgadolinium sequences (figure 1). The neuroradiographic differential diagnosis included ganglioglioma, dysembryoplastic neuroepithelial tumour and pleomorphic xanthoastrocytoma, with lesser consideration for pilocytic astrocytoma. A stereotactic biopsy of the lesion was performed, and neuropathological evaluation revealed biphasic neoplastic architecture comprising regions of densely compact eosinophilia and other, more microcystic, areas (figure 2A).

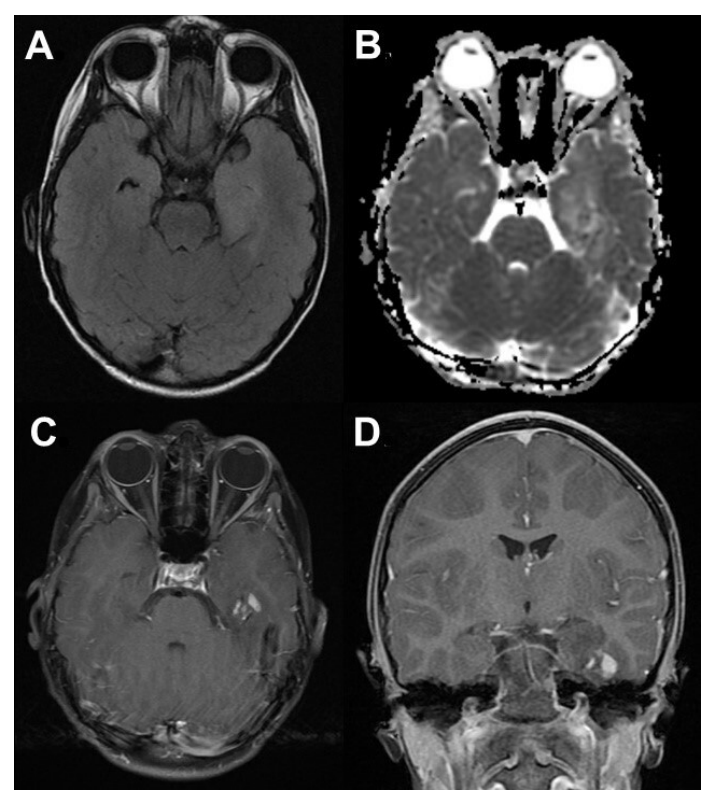

Figure 1 Neuroimaging features of a ganglioglioma in a child with Allan-Herndon-Dudley syndrome. Fluidattenuated inversion recovery MRI sequence reveals a diffuse infiltrative left temporal lobe tumour $(A)$, without reduced diffusivity $(B)$, and multiple areas of punctate enhancement on postgadolinium sequences $(C, D)$.

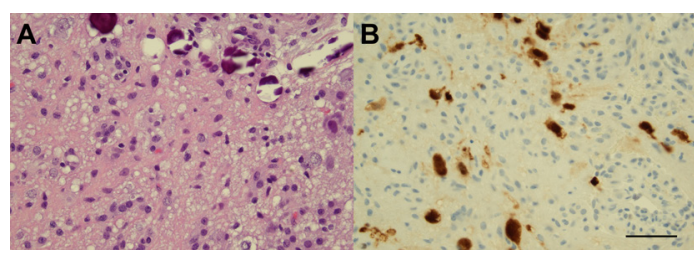

Figure 2 Neuropathological features of the ganglioglioma. (A) H\&E staining showing moderately cellular mixed proliferation of glial and neuronal cells with extensive calcification. A rare mitotic figure $(<1 / 10$ per high-power field; Ki-67 2\% of tumour cells) and perivascular lymphocytic cuffing were identified. (B) NeuN immunohistochemistry showing atypical neuronal cells highlighted with clustering and binucleation; background cells were positive for glial fibrillar acidic protein (not shown). $400 \times$ magnification; scale bar $=50 \mu \mathrm{m}$.

Piloid cells and a fibrillar background with focal Rosenthal fibres were visible within the compact eosinophilic areas. Large dysmorphic ganglion cells with vesicular chromatin were interspersed throughout the tumour, in addition to intermixed lymphocytic infiltrates. No significant mitotic activity, necrosis or microvascular proliferation were observed. Immunostaining revealed a mixed population of neoplastic cells, with some neoplastic cells and the fibrillar background immunopositive for glial fibrillar acidic protein and other neoplastic cells immunopositive for synaptophysin and NeuN (figure 2B). Sparse (2\%) Ki-67 immunopositivity and numerous leucocytes positive for leucocyte common antigen were detected; BRAF p.V600E was not observed (not shown). Microarray analysis and next-generation sequencing (NGS) of tumour tissue detected no clinically significant abnormalities. However, NGS revealed six variants of uncertain significance in PBRM1 (c.3505C>G), FAT1 (c.4434C>G), TRRAP (c.3636G >C), TSC1 (c.3008C $>$ T), DDIT3 (c.466C $>$ T) and SOX9 (c.769C $>$ T). The functional pathogenic likelihood of each variant, according to the American College of Medical Genetics and Genomics guidelines, ${ }^{1}$ was predicted using the InterVar tool based on human reference genome hg38. ${ }^{2}$ The mutations in PBRM1, FAT1, TSC1 and DDIT3 were classified as 'pathogenic', while those in TRRAP and SOX9 were predicted to be 'benign'. Overall, the neuropathological findings were considered most consistent with a diagnosis of ganglioglioma (WHO Grade 1), a rare central nervous system (CNS) tumour. ${ }^{4}$ The patient remains stable under neuroimaging 
observation more than 2 years postdiagnosis and seizure-free on antiseizure therapy.

AHDS is caused by loss-of-function mutations in X-linked SLC16A2, ${ }^{5-9}$ which encodes a transporter specific for thyroid hormone delivery to the developing brain. ${ }^{10} 11$ Cerebral hypothyroidism is severely detrimental to neurodevelopment, ${ }^{12} 13$ and clinical supplementation with thyroid hormone or its derivative has produced mixed results. ${ }^{14-17}$ AHDS consequently exhibits a profound, heterogeneous clinical presentation featuring craniofacial deformity, intellectual disability and neurological abnormalities including seizures, developmental delay and impaired mobility. ${ }^{1819}$ We report the first case of a ganglioglioma-and perhaps the first CNS tumour overall-in a paediatric patient with AHDS. Although gangliogliomas preponderantly exhibit $B R A F$ mutations, particularly p.V600E ${ }^{20-24}$ that activate MAP kinase pathways, ${ }^{21} 25$ these were not observed in our patient's ganglioglioma, which presented a novel mutation profile. Gangliogliomas are proposed to arise from dysplastic clonal precursors, ${ }^{2627}$ and thyroid hormone preeminently influences neural stem cells and progenitors. ${ }^{28-30}$ However, whether AHDS pathophysiology influenced emergence of the ganglioglioma in this patient or it arose stochastically is indeterminate and may be worthy of future investigation.

\section{Learning points}

Allan-Herndon-Dudley syndrome (AHDS) is a multisystemic developmental disorder characterised by a heterogeneous clinical presentation that can include craniofacial deformity, severe intellectual disability and neurological abnormalities.

- AHDS results from loss-of-function mutations of SLC16A2, an $X$-linked gene that encodes a transporter to deliver thyroid hormone to the brain during development.

- We present the first case of a ganglioglioma with novel molecular features in a patient with AHDS that may be worthy of future investigation.

Contributors JWA was responsible for the design and drafting of the case report. DM was responsible for the design and drafting of the case report. ML was responsible for the design and drafting of the case report. JRC was responsible for the design and drafting of the case report.

Funding The authors have not declared a specific grant for this research from any funding agency in the public, commercial or not-for-profit sectors.

Competing interests None declared.

Patient consent for publication Consent obtained from parent(s)/guardian(s).

Provenance and peer review Not commissioned; externally peer reviewed.

Case reports provide a valuable learning resource for the scientific community and can indicate areas of interest for future research. They should not be used in isolation to guide treatment choices or public health policy.

\section{REFERENCES}

1 Richards S, Aziz N, Bale S, et al. Standards and guidelines for the interpretation of sequence variants: a joint consensus recommendation of the American College of medical genetics and genomics and the association for molecular pathology. Genet Med 2015:17:405-24.

2 Niestroj L-M, May P, Artomov M, et al. Assessment of genetic variant burden in epilepsy-associated brain lesions. Eur J Hum Genet 2019;27:1738-44.

3 Li Q, Wang K. InterVar: clinical interpretation of genetic variants by the 2015 ACMGAMP guidelines. Am J Hum Genet 2017;100:267-80.
4 Ostrom QT, Patil N, Cioffi G, et al. CBTRUS statistical report: primary brain and other central nervous system tumors diagnosed in the United States in 2013-2017. Neuro Oncol 2020;22:iv1-96.

5 Friesema ECH, Grueters A, Biebermann $\mathrm{H}$, et al. Association between mutations in a thyroid hormone transporter and severe X-linked psychomotor retardation. Lancet 2004;364:1435-7.

6 Dumitrescu AM, Liao X-H, Best TB, et al. A novel syndrome combining thyroid and neurological abnormalities is associated with mutations in a monocarboxylate transporter gene. Am J Hum Genet 2004;74:168-75.

7 Holden KR, Zuñiga OF, May MM, et al. X-linked MCT8 gene mutations: characterization of the pediatric neurologic phenotype. J Child Neurol 2005;20:852-7.

8 López-Espíndola D, Morales-Bastos C, Grijota-Martínez C, et al. Mutations of the thyroid hormone transporter MCT8 cause prenatal brain damage and persistent hypomyelination. J Clin Endocrinol Metab 2014;99:E2799-804.

9 Schwartz CE, May MM, Carpenter NJ, et al. Allan-Herndon-Dudley syndrome and the monocarboxylate transporter 8 (MCT8) gene. Am J Hum Genet 2005;77:41-53.

10 Friesema ECH, Ganguly S, Abdalla A, et al. Identification of monocarboxylate transporter 8 as a specific thyroid hormone transporter. J Biol Chem 2003;278:40128-35.

11 Roberts LM, Woodford K, Zhou M, et al. Expression of the thyroid hormone transporters monocarboxylate transporter-8 (SLC16A2) and organic ion transporter-14 (SLCO1C1) at the blood-brain barrier. Endocrinology 2008;149:6251-61.

12 Kurian MA, Jungbluth $\mathrm{H}$. Genetic disorders of thyroid metabolism and brain development. Dev Med Child Neurol 2014;56:627-34.

13 Bernal J, Guadaño-Ferraz A, Morte B. Thyroid hormone transporters--functions and clinical implications. Nat Rev Endocrinol 2015;11:406-17.

14 Refetoff S, Pappa T, Williams MK, et al. Prenatal Treatment of Thyroid Hormone Cell Membrane Transport Defect Caused by MCT8 Gene Mutation. Thyroid 2021:31:713-20.

15 van Geest FS, Groeneweg S, van den Akker ELT. Long-Term efficacy of T3 analogue triac in children and adults with MCT8 deficiency: a real-life retrospective cohort study. J Clin Endocrinol Metab 2021:1-12.

16 Groeneweg S, Peeters RP, Moran C, et al. Effectiveness and safety of the triiodothyronine analogue triac in children and adults with MCT8 deficiency: an international, single-arm, open-label, phase 2 trial. Lancet Diabetes Endocrinol 2019;7:695-706

17 van Geest FS, Groeneweg S, Visser WE. Monocarboxylate transporter 8 deficiency: update on clinical characteristics and treatment. Endocrine 2021:71:689-95.

18 Groeneweg S, van Geest FS, Abacı A, et al. Disease characteristics of MCT8 deficiency: an international, retrospective, multicentre cohort study. Lancet Diabetes Endocrinol 2020;8:594-605.

19 Remerand G, Boespflug-Tanguy O, Tonduti D, et al. Expanding the phenotypic spectrum of Allan-Herndon-Dudley syndrome in patients with SLC16A2 mutations. Dev Med Child Neurol 2019;61:1439-47.

20 Pekmezci M, Villanueva-Meyer JE, Goode B, et al. The genetic landscape of ganglioglioma. acta neuropathol commun 2018;6:1-11.

21 Blümcke I, Aronica E, Becker A, et al. Low-grade epilepsy-associated neuroepithelial tumours - the 2016 WHO classification. Nat Rev Neurol 2016;12:732-40.

22 Zaky W, Patil SS, Park M, et al. Ganglioglioma in children and young adults: single institution experience and review of the literature. J Neurooncol 2018;139:739-47.

23 Schindler G, Capper D, Meyer J, et al. Analysis of BRAF V600E mutation in 1,320 nervous system tumors reveals high mutation frequencies in pleomorphic xanthoastrocytoma, ganglioglioma and extra-cerebellar pilocytic astrocytoma. Acta Neuropathol 2011:121:397-405.

24 Breton Q, Plouhinec H, Prunier-Mirebeau D, et al. BRAF-V600E immunohistochemistry in a large series of glial and glial-neuronal tumors. Brain Behav 2017;7:e00641-11.

25 Prabowo AS, lyer AM, Veersema TJ, et al. Braf V600E mutation is associated with mTOR signaling activation in glioneuronal tumors. Brain Pathol 2014;24:52-66.

26 Blümcke I, Löbach M, Wolf HK, et al. Evidence for developmental precursor lesions in epilepsy-associated glioneuronal tumors. Microsc Res Tech 1999;46:53-8.

27 Zhu JJ, Leon SP, Folkerth RD, et al. Evidence for clonal origin of neoplastic neuronal and glial cells in gangliogliomas. Am J Pathol 1997;151:565-71.

28 Vancamp P, Deprez M-A, Remmerie M, et al. Deficiency of the thyroid hormone transporter monocarboxylate transporter 8 in neural progenitors impairs cellular processes crucial for early corticogenesis. J Neurosci 2017;37:11616-31.

29 López-Juárez A, Remaud S, Hassani Z, et al. Thyroid hormone signaling acts as a neurogenic switch by repressing Sox 2 in the adult neural stem cell niche. Cell Stem Cell 2012;10:531-43.

30 Luongo C, Butruille L, Sébillot A, et al. Absence of both thyroid hormone transporters MCT8 and OATP1C1 impairs neural stem cell fate in the adult mouse subventricular zone. Stem Cell Reports 2021;16:337-53. 
Copyright 2022 BMJ Publishing Group. All rights reserved. For permission to reuse any of this content visit https://www.bmj.com/company/products-services/rights-and-licensing/permissions/

BMJ Case Report Fellows may re-use this article for personal use and teaching without any further permission.

Become a Fellow of BMJ Case Reports today and you can:

- Submit as many cases as you like

- Enjoy fast sympathetic peer review and rapid publication of accepted articles

Access all the published articles

Re-use any of the published material for personal use and teaching without further permission

Customer Service

If you have any further queries about your subscription, please contact our customer services team on +44 (0) 2071111105 or via email at support@bmj.com.

Visit casereports.bmj.com for more articles like this and to become a Fellow 